UDC $343.23(9497.1)$

Mr Svetozar R. Nikitović

\title{
PRODUŽENO KRIVIČNO DELO U NOVOM KZ SRBIJE*
}

Konstrukcija produženog krivičnog dela je nastala u Krivičnom pravu Nemačke krajem 19. veka. Međutim današnje Nemačko krivično zakonodavstvo ne predviđa u svom zakonodavstvu produženo krivično delo. Nemački teoretičari krivičnog prava su smatrali da produženo krivično delo ne predstavlja konstrukciju koja opravdava svoje egzistiranje, pa se u slučaju da se radi o izvršenju više krivičnih dela od strane jednog lica radi o realnom sticaju krivičnih dela a ne o jednom produženom krivičnom delu.

Naše krivično zakonodavstvo je i pored različitih primedaba za opstanak ovog instituta kao i pored kritika na njegov račun zadržalo produženo krivično delo kao zakonsku konstrukciju (član 61. KZ Srbije).

Novina u rešenju iz novog krivičnog zakonodavstva je što KZ Srbije predviđa produženo krivično delo kao zakonsku konstrukciju dok je u našem krivičnom zakonodavstvu do 2006. godine produženo krivično delo bilo smatrano institutom sudske prakse koji je bio u upotrebi zbog potreba prakse i rešavanja svakodnevnih konkretnih slučajeva u praksi.

Postoje krivična dela kod kojih nije moguća konstrukcija produženog krivičnog dela. To su krivična dela sa indiferentnim brojem prouzrokovanja (nabavlja, izrađuje, kupuje, prodaje).

Takođe ne može ući u produženo krivično delo naknadno nekažnjivo krivično delo (neko lice izvrši krađu pa izvrši oštećenje ukradene stvari). ${ }^{1}$

* Rad primljen: 13.09. 2010.

${ }^{1}$ M. Đorđević, Đ. Đorđević: Krivično pravo sa osnovama privrednoprestupnog i prekršajnog prava, Beograd, 2005, str. 84-85. 
Za postojanje produženog krivičnog dela neophodno je da se ispune obavezni i dopunski uslovi. Obavezni uslovi su: postojanje istih ili istovrsnih krivičnih dela, pod čime se podrazumevaju ista dela ili mogu doći u obzir privilegovani i kvalifikovani oblici istog dela. Ne može biti istovrsno delo ako su dela slična (krađa i prevara).

Drugi uslov je postojanje vremenskog kontinuiteta između izvršenih dela, s tim da taj vremenski razmak između izvršenih dela nije precizno određen, ali on treba da bude što kraći jer je neophodno da svako sledeće delo u konstrukciji produženog krivičnog dela neminovno proizilazi iz prethodnog dela.

Treći uslov je da produženo krivično delo čini jedinstveni događaj ili da predstavlja jednu celinu. ${ }^{2}$

Kako bi se ostvario ovaj uslov da se radi o jedinstvenom događaju neophodno je da se od pet dopunskih uslova ostvare makar dva takva uslova. Dopunski uslovi su: istovetnost dobra, istovetnost oštećenog, iskorišćavanje iste prilike ili iskorišćavanje iste situacije, iskorišćavanje trajnog odnosa, i jedinstveni umišljaj.

Nekada je kao obavezan uslov bio istovetnost oštećenog, ali taj uslov danas nije obavezan u kom pravcu ide i sudska praksa. (Kada optuženi u toku iste noći obije podrumske prostorije od četiri različita vlasnika i to u istom podrumu i iz njih oduzme razne stvari čini jedno produženo delo teške krađe). ${ }^{3}$

Međutim kod određenih krivičnih dela neophodno je da postoji istovetnost oštećenog (krivična dela protiv života i tela). Kada učinilac istom prilikom teško telesno povredi više lica radi se o posebnim krivičnim delima teške telesne povrede a ne o jednom produženom delu. ${ }^{4}$

Postoje krivična dela kod kojih se u praksi ne pominje produženo delo ili se to veoma retko dešava (krivična dela protiv života i tela, protiv sloboda i prava građana, protiv dostojanstva ličnosti i morala, protiv braka i porodice, protiv zdravlja ljudi).

Što se tiče uslova koji se odnosi na istovetnost dobra zanimljivo je izneti i jedno shvatanje iz Kaznenog zakonika za Knjaževinu Srbiju od 1860. koje podrazumeva da su dela istog vida a pod delima istog vida se podrazumeva krađa a ne krađa i prevara.

Produženo krivično delo predstavlja prividni realni sticaj krivičnih dela kod koga jedno lice sa više radnji ostvaruje više krivičnih dela ali se smatra da

${ }^{2}$ Z. Stojanović: Komentar KZ Srbije, Beograd, 2009. str. 235-243.

${ }^{3}$ Presuda Okružnog suda u Beogradu, Kz. 880/95, od 16. maja 1995, Sudska praksa, Beograd, broj 2/1996, str. 17.

${ }^{4}$ Presuda Okružnog suda u Beogradu, Kz. 771/96, od 7. septembra 1996, Sudska praksa, Beograd, broj 5/1997, str. 31-32. 
postoji jedno krivično delo. Prema tome kada se traži da izvršilac bude jedno lice, ono u nekom delu može da bude izvršilac a u drugom delu saučesnik. ${ }^{5}$

Postoje specifična krivična dela kod kojih je moguće postojanje produženog dela samo ako postoji iskorišćavanje iste situacije i jedinstveni umišljaj (razbojništvo). Ne postoji iskorišćavanje iste situacije pa se stoga ne može primeniti konstrukcija produženog krivičnog dela kada optuženi izvrši razbojništvo na jednom mestu a zatim se odveze kolima do drugog mesta i ponovo izvrši razbojništvo prema drugom oštećenom. ${ }^{6}$

U nekim slučajevima je neophodno da se ispuni dopunski uslov iskorišćavanja istog mesta ili iskorišćavanje istog prostora da bi se radilo o produženom krivičnom delu. Kada je učinilac više puta ušao u kuću oštećene i oduzimao stvari koje su se u kući nalazile učinio je krivično delo u produženom trajanju. $^{\text {? }}$

Određeni autori su smatrali da za postojanje produženog dela nije neophodno da se ostvare uslovi kao što su: iskorišćavanje iste prilike ili iste situacije, kao i iskorišćavanje istog mesta ili istog prostora. ${ }^{8}$

Produženo delo protiv ličnosti može postojati ako postoji istovetnost oštećenog. ${ }^{9}$

${ }^{5}$ Bora Čejović: Krivično pravo, Opšti deo, Beograd, 1999, str. 311.

${ }^{6}$ Presuda Vrhovnog suda Srbije Kz. 686/99 od 27. septembra 2001, Sudska praksa, Beograd, broj 5/2001, str. 12.

${ }^{7}$ Presuda Okružnog suda u Beogradu, Kz. 1164/96, od 17. jula 1996, Bilten Okružnog suda u Beogradu, Beograd, broj 45/1997, str. 60.

${ }^{8}$ M. Radovanović: Krivično pravo, Opšti deo, Beograd, 1975, str. 144.

${ }^{9}$ D. Jovašević: Leksikon Krivičnog prava, Beograd, 2006, str. 599-600. 